\title{
39. PRELIMINARY RESULTS OF SULFUR ISOTOPE INVESTIGATIONS ON DEEP SEA DRILLING PROJECT CORES FROM LEGS 52 AND 53
}

\author{
Harald Puchelt and Hans-W. Hubberten, \\ Institut für Petrographie und Geochemie der Universität (TH) Karlsruhe, Kaiserstr. 12, D-7500 Karlsruhe
}

\begin{abstract}
Thirty-five sulfur isotope determinations were conducted on basalts and sediments from the DSDP Legs 52 and 53. Using a combined mechanical and chemical preparation, it was possible to investigate different sulfur species in the basalts.

Sulfides occurring in globules reflect the isotopic value of mantle sulfur, with a mean of $-0.6 \%$. The "sulfate" sulfur of the basalts (including pyrite sulfur) shows a wide spread from -9.6 to $+10.7 \%$. "Sulfate" sulfur reflects sensitively secondary influences as sea water alteration or low-temperature hydrothermal activity.

Pyrites separated from the basalts are close to the mantle value. Pyrites isolated from sediment cores from Hole 418B are enriched in ${ }^{32} \mathrm{~S}$ ranging from -37.2 to $-48.1 \%$.
\end{abstract}

\section{INTRODUCTION}

Sulfur isotope investigations can elucidate the genesis of sulfur-bearing minerals and provide evidence for the provenance of the sulfur. If the assumption is true that the sulfur in basaltic rocks has been derived from the mantle (as "primary sulfur"), it should show a $\delta^{34} \mathrm{~S}$ value which lies close to the zero point of the $\delta$ scale, i.e., the sulfur isotope ratio of meteoritic sulfur (Jensen and Nakai, 1962).

Sulfur isotope investigations conducted by Schneider (1970) on terrestrial basalts from Germany, in fact, yielded sulfur isotope compositions close to this value. However, investigations by Field et al. (1976) and Krouse and Brown (1977) on epigenetic pyrites separated from basalts from Legs 34 and 37 , respectively, gave a wide spread in $\delta^{34} \mathrm{~S}$ ranging from -33.4 to $+23.0^{\circ} \%$.

Therefore, the sulfides obviously do not reflect the inferred "primary sulfur" in the isotopic composition. They could be formed by either bacterial activity or hydrothermal solution in a more complex fractionation process involving strong changes in $p \mathrm{H}$ and Eh.

In this work, we tried to analyze different sulfur species with the aim of discriminating between syngenetic and epigenetic sulfur. To compare the values of the basalts with undoubtedly sedimentary (diagenetic) sulfides, some pyrites isolated from sediments of Hole 418B have been investigated.

\section{ANALYTICAL PROCEDURE}

After crushing the rock samples, the pyrites for analyses were hand-picked under the binocular microscope, because they occur in phases up to $1 \mathrm{~mm}$ in size. The separation of $\mathrm{HCl}$-extractable sulfide and sulfate sulfur was performed according to the method described by Schneider (1970).

With this two-step procedure, sulfides as pyrrhotite, cubanite, chalcopyrite, or other sulfides of the $\mathrm{Fe}-\mathrm{Cu}-\mathrm{Ni}-\mathrm{S}$ system are decomposed first by treatment of the fine- grained sample with hydrochloric acid in the presence of aluminum. This step liberates all sulfur from sulfides, even if they occur in microscopic globules. Pyrite is not attached at this stage.

In the second step, the sample which still contains pyrite and sulfate is disintegrated with a reducing acid mixture (Thode et al., 1961). The sulfur obtained in this step is termed "sulfate" sulfur throughout this paper, with the quotation marks indicating that it is a mixture of pyrite- $S$ and sulfate-S.

All sulfur is expelled as $\mathrm{H}_{2} \mathrm{~S}$, which is precipitated as CdS. This compound is reacted to form the measuring gas $\mathrm{SO}_{2}$ for mass spectrometric determination (cf. Ricke, 1964). The ratio measurements were conducted on a VG-Micromass $1202 \mathrm{~S}$ mass spectrometer. The total error (preparation and measurement) of these determinations is less than $\pm 0.2 \%(2 \sigma)$. Approximate values for the content of the different sulfur species were obtained by weighing the $\mathrm{CdS}$ prepared for the isotopic investigations. The total error of these determinations is about \pm 20 per cent. By the procedure used in this investigation, three different sulfur species were separated: 1 . Pyrite $=$ mechanically separated pyrite; 2 . Sulfide sulfur $=$ chemically separated sulfide sulfur, possibly excluding occurring pyrite; 3 . "Sulfate" sulfur $=$ chemically separated sulfate sulfur, possibly including occurring pyrite.

\section{RESULTS}

\section{Igneous Rocks}

Eleven samples from Hole 418A were analyzed. The results are presented in Table 1 and are shown as a function of sub-bottom depth in Figure 1.

The $\delta^{34} \mathrm{~S}$ values for the sulfide sulfur cover only a small range, except for those samples which are secondarily altered (indicated by the presence of carbonate veins, pyrite, or smectite). 
TABLE 1

Sulfur Isotope Values for Basalts and One Sediment Sample From DSDP Hole 418A

\begin{tabular}{|c|c|c|c|c|c|c|c|}
\hline $\begin{array}{c}\text { Lab } \\
\text { Sample } \\
\text { Number }\end{array}$ & $\begin{array}{l}\text { DSDP } \\
\text { Core } \\
\text { Number }\end{array}$ & $\delta^{34} \mathrm{~S}(\%)$ & $\begin{array}{l}\text { de Sulfur } \\
\text { Approx. S cont. } \\
\quad \text { (ppm) }\end{array}$ & $\begin{array}{r}\text { "Sulfa } \\
\delta^{34} \mathrm{~S}(\%)\end{array}$ & $\begin{array}{l}\text { e" Sulfur } \\
\text { Approx. S cont. } \\
\quad(\text { ppm) }\end{array}$ & $\begin{array}{c}\text { Pyrites } \\
\delta^{34} \mathrm{~S}(\%)\end{array}$ & Matrix \\
\hline 2301 & 15 & -45.7 & 100 & -47.1 & 1700 & & Sediment \\
\hline 2304 & 18 & -0.9 & 870 & +10.7 & 125 & & Basalt \\
\hline 2313 & 45 & -1.8 & 350 & +4.1 & 150 & & Basalt (altered) \\
\hline 2314 & 45 & -5.3 & 350 & -9.6 & 350 & -0.4 & Basalt (+ carbonate) \\
\hline 2318 & 54 & -0.5 & 225 & +6.2 & 25 & & Basalt \\
\hline 2319 & 57 & -0.3 & 850 & +1.6 & 10 & & Basalt \\
\hline 2334 & 69 & -0.6 & 125 & +2.2 & 50 & & Basalt \\
\hline 2335 & 70 & -1.8 & 330 & +1.9 & 50 & -2.3 & Basalt (altered) \\
\hline 2337 & 70 & -0.8 & 95 & +0.7 & 12 & & Basalt \\
\hline 2342 & 74 & -1.9 & 100 & +10.6 & 130 & & Basalt (+ carbonate) \\
\hline 2343 & 77 & -10.8 & 300 & +4.5 & 55 & & Basalt (+ carbonate) \\
\hline 2345 & 85 & +0.4 & 550 & +0.1 & 65 & & Basalt \\
\hline
\end{tabular}

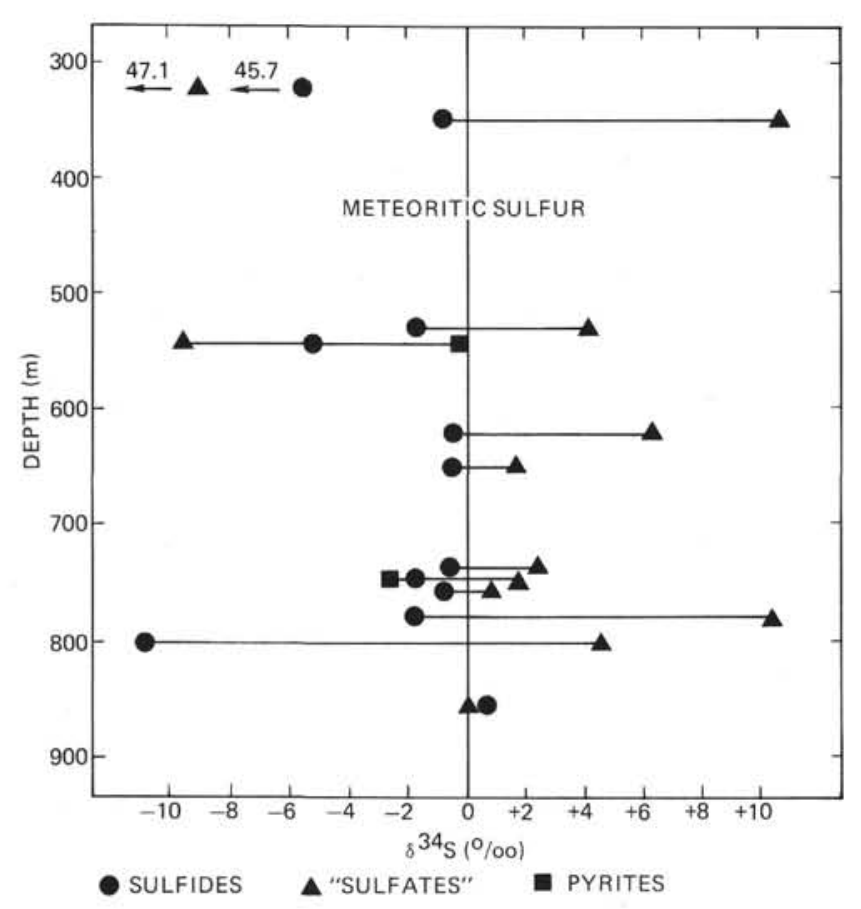

Figure 1. Sulfur isotope values of sulfide-S, "sulfate"-S, and pyrite from Hole 418 A basalts. Note that "sulfate" consists of sulfate-S and possibly occurring pyrite.

The unaltered samples vary slightly around the zero value of the $\delta$ scale, from -1.8 to $+0.4 \%$; values from the altered samples are more scattered $(-10.8$ to $-1.8 \% 00)$.

The approximate sulfide sulfur content varies from 95 ppm (a rather low value for oceanic basalts) to $870 \mathrm{ppm}$.

The "sulfate" sulfur varies in a broader range from -9.6 to $+10.7 \%$. The "sulfate" sulfur in the freshest basalts tends to have values $\leqslant 65 \mathrm{ppm}$ (except Lab Sample Number 2303), whereas a higher amount of "sulfate" sulfur indicates the provenance from a "non-basaltic" source.

The results of the two analyzed pyrites are also close to the zero value. A broad scattering, as reported by Field et al. (1976) and Krouse and Brown (1977), was not observed.
TABLE 2

Sulfur Isotope Values for Isolated Pyrites From Sediments From DSDP Hole 418B

\begin{tabular}{|c|c|c|c|}
\hline $\begin{array}{c}\text { Lab } \\
\text { Sample } \\
\text { Number }\end{array}$ & $\begin{array}{l}\text { DSDP } \\
\text { Core } \\
\text { Number }\end{array}$ & $\delta^{34} \mathrm{~S}(\%)$ & Material \\
\hline 2201 & $27, \mathrm{CC}$ & -43.0 & Py from chert \\
\hline 2202 & $28-1$ & -40.3 & Py \\
\hline 2206 & $29-1$ & -41.6 & Py \\
\hline 2210 & $30-1$ & -41.3 & Py \\
\hline 2211 a & $30-1$ & -43.1 & \\
\hline $2211 \mathrm{~b}$ & $30-1$ & -37.2 & Py \\
\hline $2211 \mathrm{c}$ & $30-1$ & $-37.3 J$ & \\
\hline 2212 & $30-2$ & -43.0 & Py \\
\hline 2214 & $31-2$ & -48.1 & Py \\
\hline
\end{tabular}

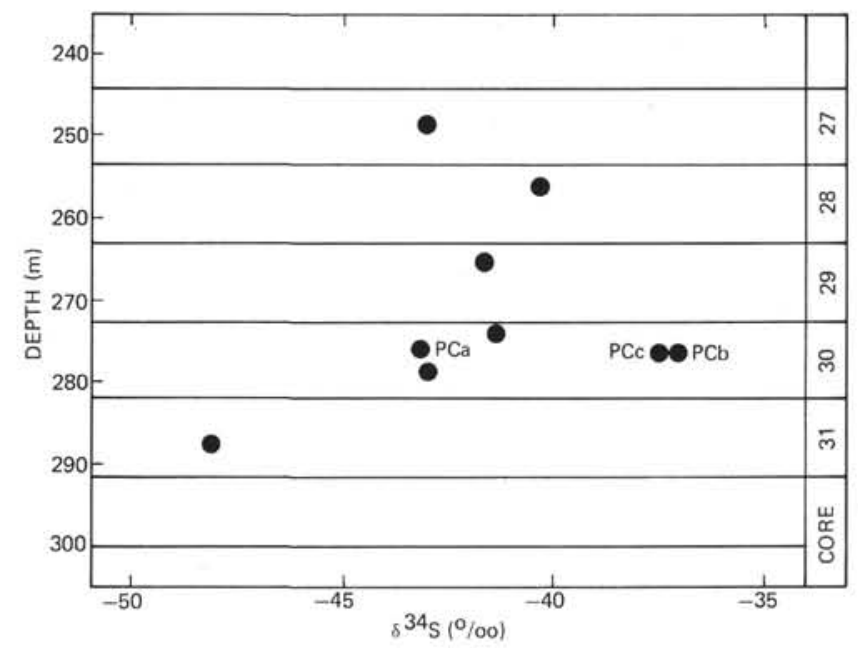

Figure 2. Sulfur isotope values of separated pyrites from Hole $418 B$ sediments.

\section{Sediments}

One sample from the sediment cover above basement at Hole $418 \mathrm{~A}$ and nine pyrite samples from sediments of the single-bit Hole 418B were analyzed. The results for Hole 
418B are presented in Table 2 and are shown as a function of depth in Figure 2. All investigated pyrites lie in a range between -37.2 and $-48.1 \%$.

The results compare well to those determined by Krouse and Brown (1977) and show typical values for sulfide sulfur generated by the activity of sulfate-reducing bacteria. An interesting observation is made in Sample 2211, where three different portions of a single pyrite aggregate were investigated.

The coarsely crystalline part (Sample 2211a) has a $\delta^{34} \mathrm{~S}$ value of $-43.1 \%$; the fine-grained (2211c) and fibrous (2211b) parts of the aggregate are enriched in ${ }^{34} \mathrm{~S}$ with values of -37.2 and $37.3 \%$, respectively.

\section{DISCUSSION}

Because submarine basalts are sometimes intensively altered either by seawater or by low-temperature hydrothermal activity, interpretation of sulfur isotope ratios in this material requires special care.

Sulfides occur in oceanic basalts in at least two generations (cf. Mathez, 1976; Bass, 1976):

1) Sulfide globules representing primary sulfur of the basaltic melt

2) Sulfide veins (pyrite or marcasite) formed by lowtemperature hydrothermal activity (?) alteration by seawater, including bacterial sulfate reduction.

To elucidate the relationship between the primary sulfur in the sulfide globules, and the secondary sulfur in the pyritic veins, it is necessary to distinguish between different sulfur species. With the preparation technique used in this paper, it was possible to distinguish three different kinds of sulfur.

\section{Sulfide Sulfur}

As pointed out by different authors (cf. Mathez, 1976; Czamanske and Moore, 1977), primary sulfide sulfur occurs predominantly in sulfide globules as a result of the immiscibility of phases in the basaltic magma. These sulfide globules mineralogically consist of pyrrhotite, pentlandite, and different $\mathrm{Cu}-\mathrm{Fe}$-sulfides with minor amounts of $\mathrm{Ni}$ (Mathez, 1976).

All these sulfides are disintegrated; with the preparation technique applied, the secondary sulfides (pyrite and possible marcasite; Bass, 1976) are not attacked. The sulfur isotope values of the primary sulfides are close to the value of meteoritic sulfur (cf. Figure 1). If only those samples were taken into account which do not show any sign of alteration, a mean value for the sulfide sulfur of $-0.6 \%$ can be calculated.

The results of the DSDP basalts from this paper are compared with those for continental basalts in Figure 3 . The DSDP mean value lies close to the mean value for continental tholeiitic basalts from West Germany (Schneider, 1970) and from Saudi Arabia (unpublished report). It is somewhat depleted in ${ }^{34} \mathrm{~S}$ compared with the mean isotopic value for sulfide globules in tholeiites from the Mid-Atlantic Ridge $(+1.05 \% 0$; Kanehira et al., 1973), and the mean value $(+1.2 \%)$ for sulfide sulfur from the Mid-Atlantic Ridge and the Indian Ocean ridge as determined by Grinenko et al. (1975).

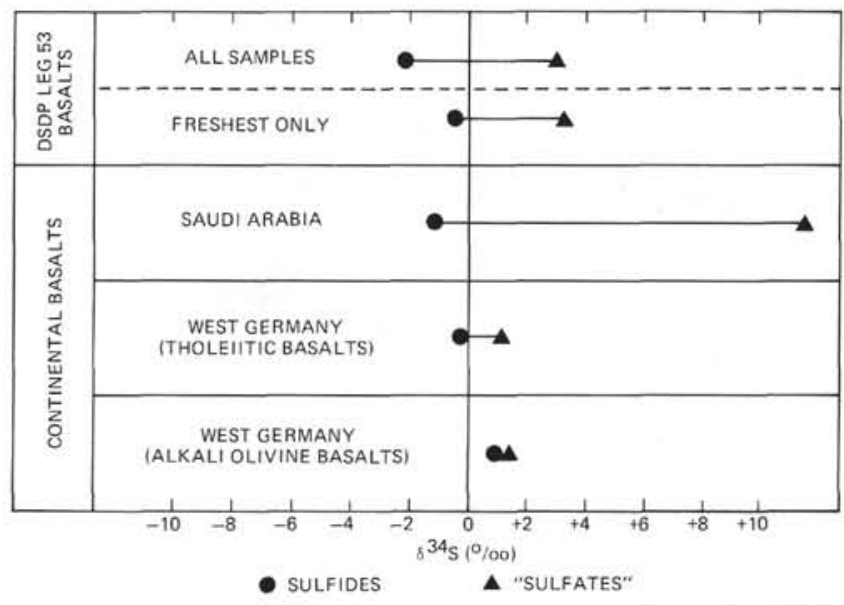

Figure 3. Comparison of the mean isotope values of sulfide$S$ and "sulfate"-S from the DSDP Leg 53 basalts with those from continental basalts from West Germany (Schneider, 1970) and Saudi Arabia (unpublished report).

It can be concluded that the primary sulfide sulfur in basalts does not show a large deviation from the value for meteoritic sulfur and, therefore, represents primary mantle sulfur. The isotope values for sulfide sulfur extracted from slightly altered samples (Lab Sample Numbers 2313, 2314, 2335,2342 , and 2343) are more negative than for the freshest samples (from -1.8 to $-10.8 \%$ ).

Since the undoubtedly secondary sulfides (pyrite, marcasite) are not extracted, a contribution of $\mathrm{HCl}$ soluble sulfide from another source (hydrothermal activity) must have occurred.

The sediment overlying the investigated basalts has isotope values (sulfide-S $=-45.7 \%$; "sulfate"- $\mathrm{S}=$ $47.1 \%$ ) which are similar to those determined in the sediments of Hole 418B.

\section{"Sulfate" Sulfur}

The sulfur isotope ratios determined for the "sulfate" sulfur are more complex to interpret because the decomposition during this preparation step does not discriminate between pyrite and sulfate. The wide variability of the "sulfate" values indicate that the sulfur species involved here are more sensitive to secondary processes.

If there is any primary sulfate sulfur preserved in these basalts, at the temperatures of basalt solidification, this sulfate should be enriched in ${ }^{34} \mathrm{~S}$ for 3 to $4 \%$ compared with the sulfide sulfur (Sakai, 1957). The mean value for "sulfate" sulfur of the freshest basalts is $+3.3 \%$. That means the "sulfate" is $3.9 \%$ heavier than the co-existing sulfide.

Extreme single values (Lab Sample Numbers 2304, 2314,2318 , and 2342) are found both for the altered and fresh basalts. It has to be assumed that the "sulfate" is either added from sea water or from hydrothermal activity. Figure 3 demonstrates that fresh deep-sea basalts and tholeiites, and alkali olivine basalts from West Germany fit the theoretical distribution of Sakai (1957) fairly well. Saudi Arabian basalts and certain deep-sea basalts indicate secondary influences. 


\section{Pyrites}

The two pyrites isolated from small veins in the basalt do not show as large deviation from the mantle value as observed by Krouse and Brown (1977) and Field et al. (1976). Further investigations on pyrites must show whether this is hole-specific or accidental.

The sulfur content in the different oxidation states of deep-sea basalts has been derived from primary or secondary sources. To elucidate the contribution of each source properly, further investigation with more sophisticated, discriminating methods are needed.

\section{ACKNOWLEDGMENT}

The investigations have been supported by a grant of the Deutsche Forschungsgemeinschaft, Bonn. This manuscript was critically reviewed by Prof. Dr. J. Hoefs, Göttingen, who made valuable suggestions. We thank all individuals and institutions who helped in the investigations and preparation of this paper.

\section{REFERENCES}

Bass, M.N., 1976. Secondary minerals in oceanic basalts, with special reference to Leg 34, Deep Sea Drilling Project. In Yeats, R.S., Hart, S.R., et al., Initial Reports of the Deep Sea Drilling Project, v. 34: Washington (U.S. Government Printing Office), p. 393-432.

Czamanske, G.K. and Moore, J.G., 1977. Composition and phase chemistry of sulfide globules in basalt from the Mid-Atlantic Ridge rift valley near $37^{\circ} \mathrm{N}$ lat, Geol. Soc. Am. Bull., v. 88 , p. 587-599.

Field, C.W., Dymond, J.R., Heath, G.R., Corliss, J.B., and Dasch, E.J., 1976. Sulfur isotope reconnaissance of epigenetic pyrite in ocean-floor basalts, Leg 34 and elsewhere. In Yeats, R.S., Hart, S.R., et al., Initial Reports of the Deep Sea Drilling Project, v.34: Washington (U.S. Government Printing Office), p. 381-384.

Grinenko, V.A., Dmitriev, L.V., Migdisov, A.A., and Sharas'kin, A.Ya., 1975. Sulfur contents and isotope compositions for igneous and metamorphic rocks from mid-ocean ridges, Geochem. Intern., v. 12, p. 132-137.

Jensen, M.L. and Nakai, N., 1962. Sulfur isotope meteorite standards, results and recommendations. In Jensen, M.L. (Ed.), Biogeochemistry of sulfur isotopes: NSF Symposium, p. 31-35

Kanehira, K., Yui, S., Sakai, H., and Sasaki, A., 1973. Sulphide globules and sulphur isotope ratios in the abyssal tholeiite from the Mid-Atlantic Ridge near $30^{\circ} \mathrm{N}$ lat, Geochem. J., v. 7, p. 89-96.

Krouse, H.R. and Brown, H.M., 1977. Sulfur isotopic composition in DSDP Leg 37 cores. In Aumento, F., Melson, W.G., et al., Initial Reports of the Deep Sea Drilling Project, v. 37: Washington (U.S. Government Printing Office), p. 621-623.

Mathez, E.A., 1976. Sulfur solubility and magmatic sulfides in submarine basalt glass, J. Geophys. Res., v. 81, p. 4269-4276.

Ricke, W., 1964. Präparation von Schwefeldioxid zur massenspektrometrischen Bestimmung des Schwefel-Isotopen-Verhältnisses ${ }^{32} \mathrm{~S} /{ }^{34} \mathrm{~S}$ in natürlichen Schwefelverbindungen, $Z$. Anal. Chem., v. 199, p. 401-413.

Sakai, H., 1957. Fractionation of sulfur isotopes in nature, Geochim. Cosmochim. Acta, v. 12, p. 150-169.

Schneider, A., 1970. The sulfur isotope composition of basaltic rocks, Contrib. Mineral. Petrol., v. 25, p.95-124.

Thode, H.G., Monster, J., and Dunford, H.B., 1961. Sulfur isotope geochemistry, Geochim. Cosmochim. Acta, v. 25, p. $159-174$. 